\title{
The Heritability of Aptitude and Exceptional Talent Across Different Domains in Adolescents and Young Adults
}

\author{
Anna A. E. Vinkhuyzen · Sophie van der Sluis • \\ Danielle Posthuma · Dorret I. Boomsma
}

Received: 30 October 2008/Accepted: 25 February 2009/Published online: 15 March 2009

(C) The Author(s) 2009. This article is published with open access at Springerlink.com

\begin{abstract}
The origin of individual differences in aptitude, defined as a domain-specific skill within the normal ability range, and talent, defined as a domain specific skill of exceptional quality, is under debate. The nature of the variation in aptitudes and exceptional talents across different domains was investigated in a population based twin sample. Self-report data from 1,685 twin pairs (12-24 years) were analyzed for Music, Arts, Writing, Language, Chess, Mathematics, Sports, Memory, and Knowledge. The influence of shared environment was small for both aptitude and talent. Additive and non-additive genetic effects explained the major part of the substantial familial clustering in the aptitude measures with heritability estimates ranging between .32 and .71 . Heritability estimates for talents were higher and ranged between .50 and .92 . In general, the genetic architecture for aptitude and talent was similar in men and women. Genetic factors contribute to a large extent to variation in aptitude and talent across different domains of intellectual, creative, and sports abilities.
\end{abstract}

Edited by Robert Plomin.

A. A. E. Vinkhuyzen ( $\square) \cdot$ D. Posthuma · D. I. Boomsma Department of Biological Psychology, VU University

Amsterdam, van der Boechorststraat 1, 1081, BT, Amsterdam, The Netherlands

e-mail: aae.vinkhuyzen@psy.vu.nl

D. Posthuma

Section Medical Genomics, VU Medical Centre, van der Boechorststraat 7, 1081, BT, Amsterdam,

The Netherlands

S. van der Sluis - D. Posthuma

Section Functional Genomics, VU University Amsterdam,

van der Boechorststraat 7, 1081, BT, Amsterdam,

The Netherlands
Keywords Talent $\cdot$ Aptitude $\cdot$ High ability $\cdot$ Heritability . Twin study

\section{Introduction}

Familial clustering of talent and giftedness has been described in various case studies of legendary families. For example, the Bach family showed a remarkable concentration of musical talents. All Bach sons grew up in a musical-social milieu, in which the young boys were trained by older family members. More recently, the Hungarian Polgar sisters became famous as advanced chess players, after being thoroughly instructed in chess by their father. Pedigrees of talented families suggest a strong familial component to exceptional ability. Case studies, however, provide insufficient information to distinguish between genetic and shared familial environmental influences. The question of whether genetic or cultural transmission causes variation in exceptional abilities and the means to develop skills through deliberate practice remains to a large extent unresolved.

In this study, the contribution of genetic influences on individual differences in aptitude and talent was investigated. Aptitude was defined as a domain-specific skill within the normal ability range of the general population. Causes of individual differences in exceptional talent were examined by explicitly distinguishing genuine outstanding ability from aptitude within the normal range. Aptitude and talent were assessed in adolescents and young adult twins from a general population sample. A self-report scale was used which distinguished nine different abilities: Music, Arts, Writing, Language, Chess, Mathematics, Sports, Memory, and Knowledge. For some of these abilities, heritability has been studied before (Howe et al. 1998; 
Lubinski et al. 2006; McGue et al. 1993; Ruthsatz et al. 2008; Sternberg et al. 1993). In a survey on the determinants of musical ability, Fuller and Thompson (1978) concluded that genetic factors contribute to musical ability in general. Coon and Carey (1989) estimated heritability to range from .10 (nonschool musical performance) to .71 (vocal performance). Based on a longitudinal study on the relation between deliberate practice and performance in Chess, De Bruin et al. (2008) concluded that deliberate practice accounted for most of the variation in performance. However, this finding leaves unresolved whether extensive practice reflects a genetic disposition to, e.g., enjoy and benefit from, playing, and practicing chess.

The majority of research on Sports focuses on sports participation, rather than aptitude or talent (e.g., Beunen and Thomis 1999; De Moor et al. 2007). MacArthur and North (2005) reviewed evidence for genetic factors on human physical performance and concluded that strong genetic influences were present.

Evidence for a biological basis for mathematical talent is reported by Benbow and Lubinski (1993) in a study on sex differences in mathematics. Biological mechanisms such as hormonal influences, medical and bodily conditions, and right hemispheric activations tend to correlate with mathematical achievement. Heritability estimates from twin studies range from .19 to .90 (Alarcon et al. 2000; Thompson et al. 1991; Wijsman et al. 2004). Regarding memory function, the majority of studies show heritability estimates around .50 (Bouchard 1998; Finkel et al. 1995; Rijsdijk et al. 2002). General Knowledge such as measured in this study is largely comparable to the Information subtest of the WAISIII (1997). Rijsdijk et al. (2002) reported a heritability of .75 for the Information subtest.

There is consensus on genetic factors playing a role in many, if not all, aspects of language (Stromswold 2001). This suggests that the ability to fluently speak multiple foreign languages might be under genetic control as well. Heritability studies on the ability to speak multiple foreign languages are, however, not available. Similarly, genetic studies on aptitude (normal population) in Writing and Arts, such as measured in the present study, have not been conducted.

Studies on causes of variation in ability in the general population are not necessarily informative about the heritability of talents and the discussion on the etiology of variation in ability is most intense with respect to variation observed in exceptional talent. Performing at an exceptional level may require more or other qualities than performing at a more ordinary level. The genetic architecture of exceptional talents may differ from the genetic architecture of aptitudes in the normal range. Studies on the heritability of exceptional talent are rare. Only a few twin studies reported high heritability estimates for talentedness in Music, Arts, Chess, and Mathematics (Coon and Carey
1989; Jenkins 2005; Walker et al. 2004), but the genetic origin of talent is still very much under debate (Ericsson et al. 1993; Ericsson and Charness 1994; Howe et al. 1998; Ruthsatz et al. 2008). The present study concerns an investigation of the genetic and environmental influences on the variation observed in both aptitude and talent across nine different domains in adolescents and young adults.

\section{Methods}

\section{Sample}

Since 1991, the Netherlands Twin Register (NTR; Boomsma et al. 2006) focuses on longitudinal survey research on health, lifestyle, personality, and psychopathology. Twins and their family-members receive a questionnaire every 2-3 years. In the present study, data from the first survey are used. Data were available for 3,370 twins (54\% women, 1,685 pairs). Zygosity of same-sex twins was based on DNA polymorphisms (434 same-sex twin pairs) or, if information on DNA markers was not available, on questions about physical similarity and confusion of the twins by family members and strangers. Agreement between zygosity diagnoses from survey and DNA data was 97\% (Willemsen et al. 2005). Twelve twin pairs (three complete and nine incomplete) were excluded because zygosity was unknown.

All five zygosity groups were well represented: monozygotic males (MZM: 16,8\%), dizygotic males (DZM: 14,5\%), monozygotic females (MZF: 22,6\%), dizygotic females (DZF: 17,6\%), and dizygotic opposite sex (DOS: $28,4 \%)$. The geographic distribution of the sample mirrored the geographic distribution of the Dutch population. The sample of participating twins was representative of the general Dutch population with regard to the educational level of the twins (CBS 2009) and the parents (Koopmans et al. 1995). Furthermore, prevalences of smoking and sport participation was comparable to other national large scale surveys (De Zwart et al. 1993; Plomp et al. 1991; Sangster and Abrahamse 1995), implying that the sample mirrored the Dutch population. Average age of the twins was 17.7 years, $(\mathrm{SD}=2.3$; range: $12.6-24.6$ years $)$.

\section{Measures}

Nine items were selected from the Talent Inventory developed by McGue et al. (1993) which concerned selfreport information on Music, Arts, Writing, Language, Chess, Mathematics, Sport, Memory, and Knowledge. These nine items required subjects to rank their own competence, compared to the general population, on an ordinal four-point scale. The first category represents people who classify themselves as less competent than 
most people. The second category represents the average (as competent as most people), the third category the above average (more competent than most people) and the fourth category represents people who classify themselves at the top-end, i.e., as being exceptionally skilled.

Music referred to singing or playing one or more instruments. Arts referred to artistic and creative activities (painting, acting). Writing referred to creative writing (letters, manuscripts, books). Language referred to the ability to speak one or more foreign languages. Chess referred to the ability to play games like chess, backgammon, and mah-jong. Mathematics referred to mathematical and numerical ability. Sports referred to athletic skills. Memory referred to general mnemonic skills (events, numbers, and facts). Knowledge referred to general and specific knowledge of facts. A detailed overview of the nine phenotypes is provided in Appendix.

The endorsement rate of the fourth (exceptional) category was very low in most phenotypes (Table 1). For the study of aptitude, categories 3 and 4 were therefore merged. For the study of exceptional talent, categories 1,2, and 3 , representing ability within the normal range, were merged and contrasted to category 4 , representing a rare and exceptional ability level.

\section{Statistical analysis}

All ordinal variables were assumed to reflect an imprecise measurement of an underlying normal distribution of liability (Falconer 1989). For the studies of aptitude and talent scores on this liability distribution could fall into 3 or 2 categories that were defined by two and one thresholds, which depend on the prevalence of the responses to the items. Since the liability is a theoretical construct, its scale is arbitrary. The liability was assumed to be standard normally distributed with zero mean and unit variance.
Aptitude

To test for differences in prevalences in aptitudes between men and women, thresholds were specified separately in both sexes. Thresholds were allowed to vary as a function of age. The second threshold was modeled as a positive deviation from the first threshold so that the second threshold was always above the first. To obtain age corrected correlations, the effect of age was modeled as a main effect of age on the first threshold and a deviation of this main effect of age on the incremental second thresholds:

$\mathbf{T}_{+1}=\mathbf{S}_{+1}+\beta_{{ }_{1}}$ Age

$\mathbf{T}_{q 2}=\left(\mathbf{S}_{q 1}+\beta_{q 1}\right.$ Age $)+\left(\mathbf{S}_{q 2}+\beta_{q_{2}}\right.$ Age $)$

$\mathrm{T}_{\widehat{\delta} 1}=\mathrm{S}_{\widehat{\delta} 1}+\beta_{\widehat{\delta} 1}$ Age

$\mathrm{T}_{\delta 2}=\left(\mathrm{S}_{\delta 1}+\beta_{\delta 1} \mathrm{Age}\right)+\left(\mathrm{S}_{\delta 2}+\beta_{\delta 2} \mathrm{Age}\right)$

in which $\mathrm{T}_{+1}$ and $\mathrm{T}_{+2}$, indicate the first and the second threshold (women). $S_{+1}$ denotes the estimate of the first threshold; $\mathbf{S}_{{ }_{2}}$ denotes the estimates of the increment of the second threshold (women). $\beta_{91}$ is the regression of age on the first threshold; $\beta_{92}$ reflects the effect of age on the increment. The term $\left(\mathrm{S}_{{ }_{2}}+\beta_{{ }_{2}} \mathrm{Age}\right)$ was restricted to be larger than, or equal to zero to ensure that the second threshold was always higher than the first. A similar model was specified in men.

First, analyses were carried out to test the effect of zygosity, sex and age on the thresholds and to estimate twin correlations. Initially, thresholds were allowed to differ for the six zygosity-by-sex groups to test for possible sibling interaction effects (model 1). Social interaction is expected to result in differences in prevalences and thus thresholds, across zygosity groups (Carey 1992). The effects of social interaction were tested within sex. The

Table 1 Number of participants and prevalences in the four original categories for men and women

\begin{tabular}{|c|c|c|c|c|c|c|c|c|c|}
\hline & \multicolumn{2}{|l|}{1} & \multicolumn{2}{|l|}{2} & \multicolumn{2}{|l|}{3} & \multicolumn{2}{|l|}{4} & \multirow{2}{*}{$\begin{array}{l}\text { Total } \\
\delta / \propto\end{array}$} \\
\hline & $\hat{0}$ & 우 & $\hat{0}$ & q & $\hat{\sigma}$ & 우 & $\hat{0}$ & 우 & \\
\hline Music & $721(48.4 \%)$ & $613(33.7 \%)$ & $537(36.0 \%)$ & $823(45.3 \%)$ & $210(14.1 \%)$ & $357(19.6 \%)$ & $22(1.5 \%)$ & $24(1.3 \%)$ & $1,490 / 1,817$ \\
\hline Arts & $901(60.5 \%)$ & $877(48.5 \%)$ & $481(32.3 \%)$ & $711(39.3 \%)$ & $83(5.6 \%)$ & $182(10.1 \%)$ & $25(1.7 \%)$ & $38(2.1 \%)$ & $1,490 / 1,808$ \\
\hline Writing & $354(23.6 \%)$ & $238(13.1 \%)$ & $923(61.4 \%)$ & $1,208(66.4 \%)$ & $215(14.3 \%)$ & $362(19.9 \%)$ & $11(.7 \%)$ & $10(.6 \%)$ & $1,503 / 1,818$ \\
\hline Language & $96(6.4 \%)$ & $86(4.7 \%)$ & $877(58.8 \%)$ & $1,007(55.6 \%)$ & $201(13.5 \%)$ & $209(11.5 \%)$ & $317(21.3 \%)$ & $510(28.1 \%)$ & $1,491 / 1,812$ \\
\hline Chess & $276(18.4 \%)$ & $561(30.9 \%)$ & $864(57.8 \%)$ & $1,097(60.4 \%)$ & $347(23.2 \%)$ & $158(8.7 \%)$ & $9(.6 \%)$ & $1(.1 \%)$ & $1,496 / 1,817$ \\
\hline Mathematics & $308(20.7 \%)$ & $708(39.1 \%)$ & $796(53.5 \%)$ & $852(47.1 \%)$ & $325(21.8 \%)$ & $232(12.8 \%)$ & $60(4.0 \%)$ & $18(1.0 \%)$ & $1,489 / 1,810$ \\
\hline Sports & $179(12.1 \%)$ & $302(16.7 \%)$ & $688(46.6 \%)$ & $1,068(59.1 \%)$ & $459(31.1 \%)$ & $342(18.9 \%)$ & $151(10.2 \%)$ & $95(5.3 \%)$ & $1,477 / 1,807$ \\
\hline Memory & $56(3.7 \%)$ & $84(4.6 \%)$ & $719(47.9 \%)$ & $1,053(57.9 \%)$ & $665(44.3 \%)$ & $649(35.7 \%)$ & $62(4.1 \%)$ & $34(1.9 \%)$ & $1,502 / 1,820$ \\
\hline Knowledge & $57(3.9 \%)$ & $135(7.5 \%)$ & $889(60.1 \%)$ & $1,431(79.1 \%)$ & $393(26.6 \%)$ & $184(10.2 \%)$ & $141(9.5 \%)$ & $59(3.3 \%)$ & $1,480 / 1,809$ \\
\hline
\end{tabular}

1 , no curiosity or no knowledge at all; 2, little knowledge and little interest, aptitude about average; 3, knowledge, interests, and aptitude above average; 4 , a superior or outstanding level 
effect of sex on the thresholds was tested by constraining the thresholds and age regression effects to be equal across sexes (model 2). The effect of age on the thresholds was tested stepwise. Since $\beta_{2}$ was modeled as a deviation of the main effect of age $\left(\beta_{1}\right)$, significance of $\beta_{2}$ was tested first (model 3: men and model 4: women). Then, the significance of $\beta_{1}$ was tested (model 5: men and model 6: women).

Age-corrected twin correlations were derived from the most parsimonious model for liability in aptitude. Analyses were carried out using the raw data option in Mx (Neale 1994; Posthuma and Boomsma 2005) and a criterion level $\alpha$ of .05 was adopted for all tests. The Mx script detailing these analyses can be found online at http://www.psy.vu.nl/ mxbib.

\section{Talent}

Talent was analyzed as a dichotomous phenotype; exceptional talent versus all other categories. As exceptional talent is rare, the endorsement rate of the fourth category was low and very few twin pairs were concordant for being exceptionally talented. To preserve a sufficient number of concordant twin pairs within the fourth category, just two zygosity groups were distinguished (MZ and DZ). Even then, empty cells were observed for some talents. To overcome this problem, contingency tables were analyzed instead of raw data and empty cells were filled with a small non-zero value (.5). All other frequencies in the table were adjusted accordingly so that the marginal values remained unaltered (Brown et al. 1983). These adjusted contingency tables were then used as input for Mx. This approach allows the study of heritability of exceptional talent, but does not allow examination of the effect of sex and age on thresholds. Therefore, polyserial correlations (Joreskog and Sorbom 2006) between age and talent (as a dichotomous phenotype) were estimated. These were all not significantly different from zero; i.e., age does not affect endorsement rates in the highest category. Furthermore, tetrachoric correlations (Joreskog and Sorbom 2006) between sex and talent (as a dichotomous phenotype) were not significant, i.e., sex does not affect endorsement rates in the highest category. Contingency table analyses do not allow for partial missingness of data. However, the percentage of missingness was small ( $\max 2.5 \%$ per trait).

Genetic analyses

Genetic models were specified in which individual differences in liability for aptitude and talent were modeled as a function of genetic and environmental effects. Genetic factors $\mathrm{A}$ and $\mathrm{D}$ and environmental factors $\mathrm{C}$ and $\mathrm{E}$ were considered. 'A' represents additive effects of alleles summed over all loci. ' $\mathrm{D}$ ' represents the extent to which the effects of alleles at a locus are not additive but interact with each other (genetic dominance). ' $C$ ' represents common environmental influences that render offspring of the same family more alike. 'E' represents all environmental influences that result in differences between members of a family. E also includes measurement error.

In a classical twin design, the effect of $C$ and D cannot be estimated simultaneously because these factors have opposite effects on the difference between MZ and DZ twin correlations. As the present study sample only included twins, the variance in liability was decomposed as due to $\mathrm{A}, \mathrm{C}$, and $\mathrm{E}$, or due to $\mathrm{A}, \mathrm{D}$, and $\mathrm{E}$. The expected covariance for $\mathrm{MZ}$ twins was $\operatorname{var}(\mathrm{A})+\operatorname{var}(\mathrm{C})$, or $\operatorname{var}(\mathrm{A})+$ $\operatorname{var}(\mathrm{D})$ in case of genetic dominance; where var(A) and var(D) represent additive genetic and non-additive genetic variance and $\operatorname{var}(\mathrm{C})$ represents variance due to $\mathrm{C}$. The expected covariance for DZ twins was $1 / 2 \operatorname{var}(\mathrm{A})+\operatorname{var}(\mathrm{C})$, or $1 / 2 \operatorname{var}(A)+1 / 4 \operatorname{var}(\mathrm{D})$ (Falconer 1989). When DZ twin correlations are at least half the $\mathrm{MZ}$ twin correlations, additive genetic effects are implied and an ACE model was fitted to the data. DZ twin correlations less than half the MZ twin correlations suggest the presence of genetic dominance. Then an ADE model was fitted to the data.

Quantitative sex differences in genetic and environmental parameters are implied when correlations in samesex twin pairs differ between men and women. In that case, genetic models were fitted separately in men and women, allowing different parameter estimates of genetic and environmental variance components.

Significance of parameters was tested by comparing the fit of nested models to the fit of less restricted models. Goodness-of-fit of these sub models was assessed by likelihood-ratio-tests. The difference in log-likelihoods between models (which follows a $\chi^{2}$ distribution) was tested. If the test is significant, the constraints imposed on the nested models are not tenable. If the difference test is not significant, the nested, more parsimonious model is to be preferred.

\section{Results}

Table 1 lists frequencies and percentages of all abilities in the four original categories. In all abilities but Language, the highest category has the lowest endorsement rate. In all abilities, except Arts and Music, the second category (average population level) accommodates the majority of the participants. 
Table 2 Model fit of aptitude scores for men and women

\begin{tabular}{|c|c|c|c|c|c|c|c|}
\hline & $\begin{array}{l}\text { Full model } \\
-2 \mathrm{LL}(d f)\end{array}$ & $\begin{array}{l}\text { Model } 1 \\
\text { Test for } \\
\text { differences in } \\
\text { thresholds } \\
\text { between zygosity } \\
\text { within sex }\end{array}$ & $\begin{array}{l}\text { Model } 2 \\
\text { Test for } \\
\text { differences in } \\
\text { thresholds } \\
\text { between sex }\end{array}$ & $\begin{array}{l}\text { Model } 3 \\
\text { Test for } \\
\text { significance of } \\
\text { the deviation of } \\
\text { age effect }\left(\beta_{2}\right) \\
\text { men }\end{array}$ & $\begin{array}{l}\text { Model } 4 \\
\text { Test for } \\
\text { significance of the } \\
\text { deviation of age } \\
\text { effect }\left(\beta_{2}\right) \text { women }\end{array}$ & $\begin{array}{l}\text { Model } 5 \\
\text { Test for } \\
\text { significance of } \\
\text { the main effect } \\
\text { of age }\left(\beta_{1}\right) \text { men }\end{array}$ & $\begin{array}{l}\text { Model } 6 \\
\text { Test for } \\
\text { significance of } \\
\text { the main effect of } \\
\text { age }\left(\beta_{1}\right) \text { women }\end{array}$ \\
\hline Music & $6,279.29(3,286)$ & 1.93 (8), NS & $\begin{array}{c}72.05(4) \\
P<.001\end{array}$ & $.90(1), \mathrm{NS}$ & $.01(1)$, NS & $\begin{array}{l}7.44(1) \\
\quad P<.01\end{array}$ & $\begin{array}{l}31.52(1) \\
\quad P<.001\end{array}$ \\
\hline Arts & $5,854.87(3,297)$ & 4.80 (8), NS & $\begin{array}{l}48.34(4) \\
\quad P<.001\end{array}$ & $.06(1), N S$ & $\begin{array}{l}8.35(1) \\
\quad P<.01\end{array}$ & $\begin{array}{c}4.93(1) \\
P<.05\end{array}$ & $\begin{array}{l}16.01(1), \\
P<.001\end{array}$ \\
\hline Writing & $5,805.49(3,320)$ & $5.67(8), \mathrm{NS}$ & $\begin{array}{l}69.87(4) \\
\quad P<.001\end{array}$ & 3.64 (1), NS & 1.44 (1), NS & .075 (1), NS & $\begin{array}{l}4.43(1) \\
\quad P<.05\end{array}$ \\
\hline Language & $5,289.95(3,282)$ & $14.42(8), \mathrm{NS}$ & $\begin{array}{r}14.22(4) \\
P<.01\end{array}$ & 1.83 (1), NS & 1.06 (1), NS & 1.439 (1), NS & $.54(1)$, NS \\
\hline Chess & $5,990.41(3,292)$ & 14.74 (8), NS & $\begin{array}{r}145.64 \\
P<.001)\end{array}$ & $.89(1), \mathrm{NS}$ & $.03(1), \mathrm{NS}$ & 3.02 (1), NS & $.22(1), \mathrm{NS}$ \\
\hline Mathematics & $6,336.94(3,306)$ & $10.51(8), \mathrm{NS}$ & $\begin{array}{r}130.84(4) \\
P<.001\end{array}$ & 1.46 (1), NS & $\begin{array}{c}6.59(1) \\
P<.05\end{array}$ & $\begin{array}{r}4.117(1) \\
P<.05\end{array}$ & $\begin{array}{l}18.15(1) \\
P<.001\end{array}$ \\
\hline Sports & $5,869.37(3,283)$ & $\begin{array}{r}16.46(8), \\
P<.05\end{array}$ & $\begin{array}{l}80.46(4), \\
\quad P<.001\end{array}$ & $\begin{array}{c}7.10(1) \\
P<.01\end{array}$ & $\begin{array}{r}10.55(1) \\
P<.01\end{array}$ & $\begin{array}{l}24.90(1) \\
P<.001\end{array}$ & $\begin{array}{l}22.20(1) \\
P<.001\end{array}$ \\
\hline Memory & $5,381.67(3,301)$ & $6.45(8), \mathrm{NS}$ & $\begin{array}{c}34.09(4) \\
P<.001\end{array}$ & $.78(1), \mathrm{NS}$ & 1.23 (1), NS & $\begin{array}{l}4.04(1) \\
\quad P<.05\end{array}$ & 2.49 (1), NS \\
\hline Knowledge & $4,566.16(3,268)$ & 8.40 (8). NS & $\begin{array}{r}208.83(4) \\
P<.001\end{array}$ & $.082(1), \mathrm{NS}$ & 1.75 (1), NS & 1.49 (1), NS & .78 (1), NS \\
\hline
\end{tabular}

For the full model the likelihood and number of degrees of freedom are presented. For all submodels $\chi^{2}$ scores, difference in degrees of freedom and $P$ values are presented

Full model. All parameters estimated: 2 thresholds for all 6 zygosity groups; main age effects men/women; deviation age effect men/women

Model 1. Model wherein thresholds are constrained equal for all zygosity groups within sex. Estimated parameters: 2 thresholds for men/women; main age effects men/women; deviation age effect men/women

Model 2. Model wherein thresholds and age coefficients are constrained equal for men and women. Estimated parameters: 2 thresholds; main age effects; deviation age effect

Model 3. Model wherein deviation of the regression coefficient of age $\left(\beta_{2}\right)$ is eliminated from the model for men

Model 4. Model wherein deviation of the regression coefficient of age $\left(\beta_{2}\right)$ is eliminated from the model for women

Model 5. Model wherein regression coefficient of the main age effect $\left(\beta_{1}\right)$ is eliminated from the model for men

Model 6. Model wherein regression coefficient of the main age effect $\left(\beta_{1}\right)$ is eliminated from the model for women

Subsequent models are tested against its previous model, provided that the fit of that previous model is acceptable. For clarity of the presentation, the most parsimonious model for all aptitudes is presented in bold

$-2 \mathrm{LL}$, minus $2 \log$ likelihood; $\beta_{1}$, coefficient of main age effect; $\beta_{2}$, deviation of the regression coefficient of age; NS, non significant; $P, P$ value

\section{Aptitude}

Table 2 shows tests for zygosity-, sex-, and age-effects on the thresholds. In all aptitudes but Sports, no significant differences between zygosity groups within sex were observed (model 1), indicating the absence of social interaction effects. A small zygosity effect on the thresholds was observed for Sports $\left[\chi^{2}=16.46(8), P=.04\right]$. However, equating thresholds in two steps (first within men, then within women) did not result in a significant deterioration of the model fit. Since the difference in model fit (model 1 vs. full model) was rather small, it was decided to equate thresholds in all zygosity groups (within sex) for all variables, including Sports. In model 2, thresholds and age regression coefficients on the thresholds were constrained to be equal between men and women. Sex effects on the thresholds were significant (all aptitudes; model 2). Men endorsed the higher categories of Arts, Chess, Mathematics, Sports, Memory, and Knowledge more often than women. Women endorsed the higher categories of Music, Writing, and Language more often than men.

Significance of both $\beta_{2}$ and $\beta_{1}$ was tested for men and women. Since $\beta_{2}$ was modeled as a deviation of the main effect of age $\left(\beta_{1}\right)$, significance of $\beta_{2}$ was tested first (model 3 and 4). Next, significance of $\beta_{1}$ was tested (model 5 and 6). Significant age effects were all negative, i.e., older participants were less inclined to endorse the higher categories. $\beta_{2}$ was significant for Sports in men (model 3) and 
for Arts, Mathematics, and Sports in women. $\beta_{1}$ was significant for Music, Arts, Mathematics, Sports, and Memory in men and for Music, Arts, Writing, Mathematics, and Sports in women. Regression coefficients of age range from .03 to -.10 . on the first threshold and from -.04 to -.06 on the increment. Although the age range in this sample was not large (12.6-24.6 years), age influences self reported aptitudes. Maturation effects during puberty (e.g., fast maturation may lead to higher aptitudes at a relatively earlier age), or the ability to assess one's own aptitude, may be of importance within this age range. Non-significant age effects were eliminated from the genetic models. The most parsimonious model for all aptitudes is presented in bold.

Table 3 lists the polychoric twin correlations and their confidence intervals. For all variables, MZ twin correlations exceeded the DZ twin correlations suggesting genetic influences. In Chess, Mathematics, Writing, and Memory, DZ correlations were smaller than half the MZ correlations, implying the presence of genetic dominance. ADE models were fitted to these four aptitudes, while ACE models were fitted to the other five. Twin correlations were equal in men and women for all aptitudes but Sports $\left[\Delta \chi^{2}(2)=19.027\right.$, $P<.001]$. Higher heritability was implied in men, while a larger influence of shared environmental factors was implied in women. Correlations of $\mathrm{A}$ and $\mathrm{C}$ were fixed to .5 and 1 , respectively, in DZ same-sex and in DZ oppositesex pairs.

Table 4 lists the genetic model fitting results; preferred models are presented in bold. First, a full ACE or ADE model was evaluated with different parameter estimates for men and women (model 1). Next, the difference between men and women in magnitude of the genetic and environmental components was tested (model 2). Significance of $\mathrm{A}$ and $\mathrm{C}$ or $\mathrm{D}$ was tested by constraining the relevant parameters to zero (models 3-5).
A full ACE model was preferred for Music and Sports (women). A full ADE model was preferred for Chess, Mathematics, and Memory. An AE model was preferred for Arts, Language, Sports (men), and Knowledge. Quantitative sex differences were observed in Music and Sports (model 2).

The proportion of variance explained by additive genetic factors was low in Chess (.01), Mathematics (.11), and Memory (.01), while the proportion of variance accounted for by dominance genetic factors was high for Chess (.48), Mathematics (.56), and Memory (.47) (Table 5). Since dominance deviation are not generally expected without a contribution of additive genetic factors, relatively low proportions of additive genetic variance in Chess, Mathematics, and Memory are not eliminated from the model.

The proportion of variance explained by additive genetic factors was relatively high in Music (.66, men), Arts (.60), and Sports (men: .64). Shared environmental variance components were not significant in Arts, Language, Sports (men), and Knowledge, whereas this components were significant in Music (men: .09, women: .48) and in Sports (women: .51).

\section{Talent}

As stated, contingency tables were analyzed for exceptional talent. Genetic analysis was not conducted for Chess due to the very low endorsement rate of the exceptional ability category (Table 1). Table 6 lists tetrachoric twin correlations and their confidence intervals. For all talents, MZ twin correlations exceeded the DZ twin correlations implying genetic influences. For Arts, Writing, Mathematics, Sports, Memory, and Knowledge, DZ correlations were smaller than half the MZ correlations, implying the presence of genetic dominance. ADE models were fitted to

Table 3 Sex and age corrected polychoric twin correlations (95\% confidence intervals) for aptitude

\begin{tabular}{llllll}
\hline & $\begin{array}{l}\text { rMZM } \\
n=283,16.8 \%\end{array}$ & $\begin{array}{l}\text { rDZM } \\
n=245,14.5 \%\end{array}$ & $\begin{array}{l}\text { rMZF } \\
n=381,22.6 \%\end{array}$ & $\begin{array}{l}\text { rDZF } \\
n=297,17.6 \%\end{array}$ & $\begin{array}{l}\text { rDOS } \\
n=479,28.4 \%\end{array}$ \\
\hline Music & $.74(.65-.81)$ & $.45(.30-.58)$ & $.80(.74-.85)$ & $.63(.53-.71)$ & $.42(.32-.51)$ \\
Arts & $.54(.40-.66)$ & $.36(.19-.51)$ & $.64(.55-.71)$ & $.29(.14-.42)$ & $.23(.10-.34)$ \\
Writing & $.47(.33-.59)$ & $.11(.01-.26)$ & $.46(.33-.57)$ & $.09(.01-.23)$ & $.23(.12-.33)$ \\
Language & $.63(.50-.73)$ & $.42(.26-.55)$ & $.76(.67-.82)$ & $.39(.25-.51)$ & $.31(.20-.42)$ \\
Chess & $.48(.34-.59)$ & $.20(.05-.35)$ & $.51(.38-.62)$ & $.07(.01-.22)$ & $.01(.01-.11)$ \\
Mathematics & $.66(.56-.74)$ & $.19(.03-.33)$ & $.68(.60-.75)$ & $.30(.16-.43)$ & $.14(.03-.25)$ \\
Sports & $.62(.51-.72)$ & $.38(.23-.52)$ & $.80(.74-.85)$ & $.66(.55-.75)$ & $.16(.05-.27)$ \\
Memory & $.43(.27-.57)$ & $.15(.01-.32)$ & $.51(.40-.62)$ & $.01(.01-.07)$ & $.19(.06-.31)$ \\
Knowledge & $.58(.45-.69)$ & $.30(.11-.46)$ & $.51(.37-.63)$ & $.25(.07-.42)$ & $.31(.19-.42)$ \\
\hline
\end{tabular}

For each aptitude, correlations were obtained from the most parsimonious model (Table 2)

rMZM, correlation monozygotic males; rDZM, correlation dizygotic males; rMZF, correlations monozygotic females; rDZF, correlation dizygotic females; rDOS, correlation opposite sex twins; $n$, number of twin pairs 
Table 4 Model fitting results for aptitude

\begin{tabular}{|c|c|c|c|c|c|c|c|}
\hline \multicolumn{2}{|c|}{ Models } & vs & $-2 \mathrm{LL}$ & Estimated parameters & $\chi^{2}$ & $\Delta d f$ & $P$ \\
\hline \multicolumn{8}{|c|}{ Music } \\
\hline 1 & ACE & & $6,303.93$ & 10 & & & \\
\hline 2 & ACE no sex diff. & 1 & $6,314.59$ & 8 & 10.66 & 2 & $<.01$ \\
\hline $3 a$ & $\mathrm{AE}$ men & 1 & $6,311.95$ & 9 & 8.02 & 1 & $<.01$ \\
\hline $4 a$ & CE men & 1 & $6,319.73$ & 9 & 15.80 & 1 & $<.001$ \\
\hline $3 b$ & $\mathrm{AE}$ women & 1 & $6,322.01$ & 9 & 18.08 & 1 & $<.001$ \\
\hline $4 \mathrm{~b}$ & CE women & 1 & $6,314.20$ & 9 & 10.27 & 1 & $<.01$ \\
\hline \multicolumn{8}{|c|}{ Arts } \\
\hline 1 & $\mathrm{ACE}$ & & $5,861.56$ & 11 & & & \\
\hline 2 & ACE no sex diff. & 1 & $5,865.16$ & 9 & 3.60 & 2 & NS \\
\hline 3 & $\mathbf{A E}$ & 2 & $5,865.16$ & 8 & $\mathbf{0}$ & 1 & NS \\
\hline 4 & $\mathrm{CE}$ & 2 & $5,898.00$ & 8 & 32.84 & 1 & $<.001$ \\
\hline 5 & $\mathrm{E}$ & 2 & $6,057.93$ & 7 & 192.77 & 2 & $<.001$ \\
\hline \multicolumn{8}{|c|}{ Writing } \\
\hline 1 & ADE & & $5,818.64$ & 9 & & & \\
\hline 2 & ADE no sex diff. & 1 & $5,818.68$ & 7 & .04 & 2 & NS \\
\hline 3 & $\mathbf{A E}$ & 2 & $\mathbf{5 , 8 2 1 . 4 2}$ & 6 & 2.75 & 1 & NS \\
\hline 4 & $\mathrm{E}$ & 2 & $5,909.02$ & 5 & 87.60 & 2 & $<.001$ \\
\hline \multicolumn{8}{|c|}{ Language } \\
\hline 1 & ACE & & $5,309.25$ & 8 & & & \\
\hline 2 & ACE no sex diff. & 1 & $5,314.18$ & 6 & 4.93 & 2 & NS \\
\hline 3 & $\mathbf{A E}$ & 2 & $5,314.20$ & 5 & .20 & 1 & NS \\
\hline 4 & $\mathrm{CE}$ & 2 & $5,357.59$ & 5 & 43.39 & 1 & $<.001$ \\
\hline 5 & $\mathrm{E}$ & 2 & $5,589.30$ & 4 & 275.10 & 2 & $<.001$ \\
\hline \multicolumn{8}{|c|}{ Chess } \\
\hline 1 & $\mathrm{ADE}$ & & $6,009.91$ & 8 & & & \\
\hline 2 & ADE no sex diff. & 1 & $6,015.46$ & 6 & 5.55 & 2 & NS \\
\hline 3 & $\mathrm{AE}$ & 2 & $6,029.33$ & 5 & 13.87 & 1 & $<.001$ \\
\hline \multicolumn{8}{|c|}{ Mathematics } \\
\hline 1 & $\mathrm{ADE}$ & & $6,338.03$ & 11 & & & \\
\hline 2 & ADE no sex diff. & 1 & $6,341.02$ & 9 & 2.99 & 2 & NS \\
\hline 3 & $\mathrm{AE}$ & 2 & $6,353.47$ & 8 & 12.45 & 1 & $<.001$ \\
\hline \multicolumn{8}{|c|}{ Sports } \\
\hline 1 & $\mathrm{ACE}$ & & $5,891.81$ & 12 & & & \\
\hline 2 & ACE no sex diff. & 1 & $5,935.82$ & 10 & 44.00 & 2 & $<.001$ \\
\hline $3 \mathbf{a}$ & AE men & 1 & $5,892.26$ & 11 & .45 & 1 & NS \\
\hline $4 a$ & CE men & 1 & $5,910.68$ & 11 & 18.42 & 1 & $<.001$ \\
\hline $5 \mathrm{a}$ & E men & 1 & $5,990.60$ & 10 & 79.92 & 2 & $<.001$ \\
\hline $3 b$ & $\mathrm{AE}$ women & $3 \mathrm{a}$ & $5,920.64$ & 10 & 28.38 & 1 & $<.001$ \\
\hline $4 b$ & CE women & $3 a$ & $5,907.27$ & 10 & 15.01 & 1 & $<.001$ \\
\hline \multicolumn{8}{|c|}{ Memory } \\
\hline 1 & $\mathrm{ADE}$ & & $5,405.179$ & 9 & & & \\
\hline 2 & ADE no sex diff. & 1 & $5,405.263$ & 7 & .08 & 2 & NS \\
\hline 3 & $\mathrm{AE}$ & 2 & $5,416.659$ & 6 & 11.396 & 1 & $<.001$ \\
\hline \multicolumn{8}{|c|}{ Knowledge } \\
\hline 1 & ACE & & $4,578.864$ & 8 & & & \\
\hline 2 & ACE no sex diff. & 1 & $4,579.644$ & 6 & .78 & 2 & NS \\
\hline 3 & $\mathbf{A E}$ & 2 & $4,579.807$ & 5 & .16 & 1 & NS \\
\hline 4 & $\mathrm{CE}$ & 2 & $4,595.169$ & 5 & 15.36 & 1 & $<.001$ \\
\hline 5 & $\mathrm{E}$ & 2 & $4,713.440$ & 4 & 133.63 & 2 & $<.001$ \\
\hline
\end{tabular}


Table 5 Proportions of variance for the best fitting models and full models for aptitude in Dutch twins across 9 domains of intellectual, creative, and sports abilities

For music and sports, parameter estimates are shown for men and women separately

$a^{2}$, additive genetic effects; $d^{2}$, dominance genetic effects; $c^{2}$, common environmental effects; $e^{2}$, unique environmental effects Full model is presented in italic

\begin{tabular}{llccc}
\hline Variable & $a^{2}$ & $d^{2}$ & $c^{2}$ & $e^{2}$ \\
\hline Music (men) & $.66(.52-.77)$ & - & $.08(.04-.16)$ & $.25(.19-.34)$ \\
Music (women) & $.30(.16-.36)$ & - & $54(.48-.68)$ & $.16(.12-.22)$ \\
Arts & $.60(.53-.66)$ & - & - & $.40(.34-.47)$ \\
Full model & $.60(.53-.66)$ & & $.00(.00-.13)$ & $.40(.34-.47)$ \\
Writing & $.43(.35-.50)$ & - & - & $.57(.50-.65)$ \\
Full model & $.18(.00-.44)$ & $.27(.0-.52)$ & & $.55(.47-.63)$ \\
Language & $.71(.65-.76)$ & - & - & $.29(.24-.35)$ \\
Full model & $.70(.50-.76)$ & & $.01(.00-.17)$ & $.29(.24-.36)$ \\
Chess & $.01(.00-.17)$ & $.48(.28-.56)$ & - & $.52(.44-.61)$ \\
Mathematics & $.11(.00-.41)$ & $.56(.25-.73)$ & - & $.33(.27-.39)$ \\
Sports (men) & $.64(.51-.72)$ & - & - & $.36(.28-.47)$ \\
Full model & $.57(.41-.68)$ & & $.06(.01-.18)$ & $.37(.28-.48)$ \\
Sports (women) & $.29(.09-.53)$ & - & $.51(.29-.69)$ & $.20(.15-.26)$ \\
Memory & $.01(.00-.20)$ & $.47(.25-.55)$ & - & $.52(.45-.62)$ \\
Knowledge & $.56(.47-.63)$ & - & - & $.44(.37-.53)$ \\
Full model & $.51(.26-.63)$ & $.04(.00-.23)$ & & $.45(.37-.55)$ \\
\hline
\end{tabular}

Table 6 Tetrachoric twin correlations (95\% confidence intervals) for talent

\begin{tabular}{lll}
\hline & $\mathrm{rMZ}$ & $\mathrm{rDZ}$ \\
\hline Music & $.92(.73-.98)$ & $.49(.11-.76)$ \\
Arts & $.61(.27-.84)$ & $.05(-.45-.48)$ \\
Writing & $.83(.28-.98)$ & $.38(-.25-.79)$ \\
Language & $.72(.64-.80)$ & $.48(.37-.57)$ \\
Mathematics & $.89(.74-.96)$ & $.04(-.48-.48)$ \\
Sports & $.85(.74-.92)$ & $.40(.23-.55)$ \\
Memory & $.59(.23-.82)$ & $.24(-.06-.49)$ \\
Knowledge & $.65(.47-.79)$ & $.20(-.02-.41)$ \\
\hline
\end{tabular}

rMZ, correlation monozygotic twins; rDZ, correlation dizygotic twins

these abilities, while ACE models were fitted to Music and Language.

Table 7 lists the genetic model fitting results; preferred models are presented in bold. None of the dominance genetic effects were statistically significant. Variation in all talents is explained by additive genetic and non-shared environmental factors (Table 8). Shared environmental factors were only significant for Language, explaining $23 \%$ of the variation. Noticeable are the high heritability estimates for Music (.92), Writing (.83), Mathematics (.87), and Sports (.85).

\section{Discussion}

The aim of this study was to investigate causes of human variation observed in self-reported aptitude and talent across nine different domains.
For aptitudes, sex differences in prevalences were observed across nearly all domains. Women were more inclined to classify themselves into higher categories in Music, Writing, and Language, while men classified their own performance more often as above average in Arts, Chess, Mathematics, Sports, Memory, and Knowledge.

Despite the small age range (12-24 years), age effects on aptitudes were significant in Music, Arts, Writing (women), Mathematics, Sports, and Memory (men). Older participants were less inclined to classify themselves in the highest categories. The age effect might be attributable to differences in the ability to compare oneself with other people. Younger participants may be less capable in comparing themselves with other people of similar age. Alternatively, individual differences in maturation could create true differences among adolescents and young adults. Sex and age effects were observed in the study of aptitude, while no sex or age effects were observed in the study of talent. Polychoric correlations between sex and talent and polyserial correlations between age and talent were not significant, suggesting that age is not related to the expression of rare talents.

Results of the genetic analyses clearly demonstrate that in both aptitude and talent, genetic factors contribute to a large extent to the observed variation. Moreover, a comparison between the relative contribution of genetic and environmental factors on aptitudes and talents showed a highly similar contribution of genetic factors for Arts and a decreased genetic contribution for Language. Increased contribution of genetic factors in exceptional talent was observed for Music, Writing, Mathematics, Sports, Memory, and Knowledge: heritability estimates of the majority of these talents exceed the upper bound of the confidence 
Table 7 Model fitting results for talent

\begin{tabular}{lllllll}
\hline Models & vs & $\chi^{2}$ & $\begin{array}{l}\text { Estimated } \\
\text { parameters }\end{array}$ & $\Delta \chi^{2}$ & $\Delta d f$ & $P$ \\
\hline
\end{tabular}

\section{Music}

1 ACE

$\begin{array}{lllll}2 & \mathrm{AE} & 1 & \mathbf{3 8} & \mathbf{2}\end{array}$

$\begin{array}{lllll}3 & \mathrm{CE} & 1 & 9.378 & 2\end{array}$

$\begin{array}{lllll}4 & \mathrm{E} & 2 & 49.222 & 1\end{array}$

Arts

1 ADE $\quad 2.95 \quad 3$

$\begin{array}{lllll}2 & \mathrm{AE} & \mathbf{1} & \mathbf{3 . 8 2} & \mathbf{2}\end{array}$

$\begin{array}{lllll}3 & \mathrm{E} & 2 & 13.73 & 1\end{array}$

Writing

1 ADE $\quad 17.64 \quad 3$

$\begin{array}{lllll}2 & \mathrm{AE} & 1 & \mathbf{1 7 . 6 4} & 2\end{array}$

$\begin{array}{lllll}3 & \mathrm{E} & 2 & 85.71 & 1\end{array}$

Language

1 ACE

$5.67 \quad 3$

$\begin{array}{lllll}2 & \mathrm{AE} & 1 & 9.96 & 2\end{array}$

$\begin{array}{lllll}3 & \mathrm{CE} & 1 & 20.40 & 2\end{array}$

Mathematics

1 ADE

$$
6.18 \quad 3
$$

$\begin{array}{lllll}2 & \mathrm{AE} & 1 & 8.77 & 2\end{array}$

$\begin{array}{lllll}3 & \mathrm{E} & 2 & 67.66 & 1\end{array}$

Sports

1 ADE $\quad 2.3 \quad 3$

$\begin{array}{lllll}2 & \text { AE } & 1 & 2.49 & 2\end{array}$

$\begin{array}{lllll}3 & \mathrm{E} & 2 & 116.60 & 1\end{array}$

Memory

$1 \quad$ ADE $\quad 3.59 \quad 3$

$\begin{array}{lllll}2 & \text { AE } & 1 & 3.74 & 2\end{array}$

$\begin{array}{lllll}3 & \mathrm{E} & 2 & 15.64 & 1\end{array}$

Knowledge

1 ADE $\quad 2.96 \quad 3$

$\begin{array}{lllll}2 & \mathrm{AE} & 1 & 4.17 & 2\end{array}$

$\begin{array}{lllll}3 & \mathrm{E} & 2 & 42.71 & 1\end{array}$

$\begin{array}{lll}\mathbf{. 0 3} & \mathbf{1} & \mathbf{N S} \\ 9.03 & 1 & <.01 \\ 48.84 & 1 & <.001\end{array}$

$\begin{array}{lll}.87 & 1 & \text { NS }\end{array}$

$9.91 \quad 1<.01$

1 NS

$68.07 \quad 1<.001$

$4.30 \quad 1<.05(.038)$

$10.44 \quad 1<.01$

$\begin{array}{lll}2.59 & 1 & \text { NS }\end{array}$

$58.89 \quad 1<.001$

$\begin{array}{lll}.10 & 1 & \text { NS }\end{array}$

$114.11 \quad 1<.001$

vs, compared to model; $\chi^{2}$, chi square test statistic; $\Delta \chi^{2}$, difference chi square; $\Delta d f$, difference degrees of freedom; $P, P$ value

intervals around the heritability estimates of aptitude. These outcomes suggest that genetic factors are essential for outstanding levels of ability.

Some methodological limitations regarding the comparison between aptitude and talent should be noted. First, the low endorsement rates of the exceptional category and the use of contingency tables precluded the simultaneous investigation of sex and age effect in the genetic analyses of talent. Neglecting possible effects of sex and age could bias estimates of additive genetic effects and shared environmental effects, respectively. However, non-significant correlations between talent (as a dichotomous phenotype) and sex and age were found.

The dominance genetic effects reported for aptitudes were not seen for talent. This might be due to a reduction in statistical power in the dichotomous analyses of talent. In general, of the use of dichotomous measures requires a larger sample size to detect genetic dominance. Furthermore, a low prevalence (i.e., rare talent) requires a much larger sample size compared to an 'optimal' prevalence (50\%; Neale et al. 1994). Given the present sample size with a prevalence of $5 \%$, genetic dominance must explain at least $78 \%$ of the total variance (additive genetic variance $=10 \%$ ) to reject an $\mathrm{AE}$ model with a power of $80 \%$ when the true world model is ADE. Third, estimates of E are generally lower in the analyses of talent, compared to the analyses of aptitude, suggesting that unique environment contributes less to variation or that measurement error is lower. For dichotomous measures, more measurement error might be expected. Yet, classifying oneself as either exceptionally talented or not, may not be that prone to misclassification, resulting in a relatively reliable dichotomous measure of talent.

Any trait with a heritability of less then unity (Eysenck 1995), will show regression towards the mean. Highly talented people are therefore less likely to have similarly talented children. In his theory of genius and creativity, Eysenck (1995) argues that "genius would be seen as a highly unlikely segregation of genes, occurring very rarely for a few individuals only" and that complex human traits such as genius and talent are likely to be controlled by combinations of interacting genes called epistasis or emergenesis (Lykken et al. 1992). Such traits may be heritable but resemblance will not be seen in first degree relatives while $\mathrm{MZ}$ twins do bear a resemblance to each other. Although we observe some DZ correlations that are relatively low compared to $\mathrm{MZ}$ correlations for a few talents, for most talents substantial additive genetic variance is also suggested.

It is possible that individual differences in aptitudes and talents are associated with IQ and that part of the heritability is shared with genetic influences on IQ. For 295 participants from this sample, information on IQ was available (Rijsdijk and Boomsma 1997). Participants with high IQ were slightly overrepresented in the highest category of the Talent Inventory. Polyserial correlations (Joreskog and Sorbom 2006) between talents and IQ ranged from $.12($ Sport $\times$ IQ, ns) to .28 (Mathematics $\times$ IQ, $P<.001)$.

Findings about genetic influences on individual differences in aptitude from the present study are in line with findings from previous heritability studies on Music (Coon and Carey 1989), Mathematics (Thompson et al. 1991; Alarcon et al. 2000), Sports (Beunen and Thomis 1999; 
Table 8 Proportions of variance (95\% confidence intervals) of the best fitting models and full models for talent across 8 domains of intellectual, creative and sports abilities

\begin{tabular}{lllll}
\hline Variable & $a^{2}$ & $d^{2}$ & $c^{2}$ & $e^{2}$ \\
\hline Music & $.92(.74-.98)$ & & - & $.08(.02-.26)$ \\
Full model & $86(.22-.98)$ & & $06(.00-.62)$ & $.08(.02-.27)$ \\
Arts & $.56(.22-.80)$ & - & - & $.44(.20-.78)$ \\
Full model & $.00(.00-.78)$ & $.60(.00-.83)$ & & $.40(.17-.74)$ \\
Writing & $.83(.33-.98)$ & - & - & $.17(.02-.67)$ \\
Full model & $88(.00-.95)$ & $.00(.00-.95)$ & & $.12(.05-.26)$ \\
Language & $.50(.25-.75)$ & - & $.23(.01-.43)$ & $.27(.20-.36)$ \\
Mathematics & $.87(.72-.95)$ & - & - & $.13(.05-.28)$ \\
Full model & $.00(.00-.93)$ & $.88(.00-.96)$ & & $.12(.04-.26)$ \\
Sports & $.85(.74-.92)$ & - & - & $.15(.08-.26)$ \\
Full model & $.74(.07-.92)$ & $.10(.00-.80)$ & & $.15(.08-.26)$ \\
Memory & $.56(.26-.79)$ & - & - & $.44(.21-.75)$ \\
Full model & $.35(.00-.79)$ & $.25(.00-.82)$ & & $.41(.18-.74)$ \\
Knowledge & $.62(.44-.76)$ & - & - & $.38(.24-.56)$ \\
Full model & $.14(.00-.74)$ & $.51(.00-.79)$ & & $.35(.21-.53)$ \\
\hline
\end{tabular}

Boomsma et al. 1989; Bouchard and Malina 1983; Macarthur and North 2005; Maia et al. 2002; Stubbe et al. 2005; Stubbe et al. 2006), Memory (Bouchard 1998; Finkel et al. 1995), and Knowledge (Rijsdijk et al. 2002).

In contrast to the majority of research on aptitude and talent, self-report questionnaires were used in the present study. Self-report questionnaires can easily be administered to a large sample, representative of the general population. Since it is not the ability itself that is studied, but its etiology in terms of genetic and environmental influences, a good representation of the general population, in which all levels of aptitude and talent are present, is required. The validity of self-report data might, however, be questioned. People may differ in the extent to which they are capable of comparing their own ability to that of others, a capacity which may be related to age and in their readiness to portray themselves as more or less talented then others. In addition, people are likely to compare their own competence with that of people in their proximity. If one's environment is correlated with one's phenotype, people will be less likely to classify themselves in the lower or higher end of the population. Yet, the distribution of the prevalences of the majority of the traits in this study was in line with the expected distribution for the general population, with mean scores for the majority of the participants and exceptional scores for only a very small part of the sample. Regarding Language, the majority of the participants classified themselves into the two highest categories.

No information is available on the reliability of the single items that were analyzed. However, heritability cannot exceed the reliability of a trait. As heritability for most items is not low, we conclude that reliability is not low either (Bouchard et al. 1990).
The high endorsement rate of the two highest ability levels for Language indicates that this item of the Talent Inventory does not discriminate well within the Dutch population. In the Netherlands, foreign languages are taught in nearly all high schools. As a result, all people who completed high school are likely to endorse one of the two highest categories; this original Language item seems therefore unsuited as a measure of linguistic talent in this sample.

Genetic influences on variation in self-rated talent were earlier described by McGue et al. (1993). In that study, no distinction was made between aptitude and exceptional talent. The study by McGue et al. as well as the present study report considerable genetic influences on talents and aptitudes. However, other studies (de Bruin et al. 2007; de Bruin et al. 2008; Ericsson and Charness 1994; Howe et al. 1998) question these findings and emphasize that excelling only occurs after large amounts of deliberate practice. According to Gagne (1999), experts in music are likely to benefit more from deliberate practice than average musicians do, but extensive practice remains indispensable. Such explanations point to the possible importance of gene-environment correlations. Genetic factors that account for higher abilities may also contribute to a more favorable environment for that ability to flourish in (Plomin et al. 1977). In a recent review, Ruthsatz et al. (2008) proposed a multi-factor view as an explanation for the achievement of outstanding musical abilities. Innate talent, practice and intelligence together accounted for more of the variance in music performance than practice alone.

Giftedness in a particular domain is likely to generate various aspects of being rewarded for personal qualities. Talented people are more rewarded compared to people within the normal range. Reward could possibly lead to more training and practice, more social opportunities, more 
support and even more rewards. That is, to be rewarded could initiate a reciprocal process of success that leads to even more practice and higher levels of performance (Dickens and Flynn 2001). This gene-environment correlation view on the variability observed in aptitude and talent thus unites the views that practice is indispensible and that heritability at the same time is clearly of importance as well and merits further research. This also implies that high heritability does not mean environmental influences to be unimportant. To reach exceptional levels of ability, deliberate practice is indispensible even for people with a genetic predisposition to develop a talent. This study does, however, show that differences in genetic make-up control individual differences in self-reported aptitude and talent.

Acknowledgments This project was supported by VU-USF 96/22, NWO 575-25-006, NWO/SPI 56-464-14,192, NWO 480-04-004 and NWO/MaGW VIDI-016-065-318.

Open Access This article is distributed under the terms of the Creative Commons Attribution Noncommercial License which permits any noncommercial use, distribution, and reproduction in any medium, provided the original author(s) and source are credited.

\section{Appendix}

Talent inventory in the 1991 survey

The response items in the questionnaire appear in the reverse order to the categories used in the analyses.

The next questions concern special talents you may possess. The first category describes exceptional talent. The third category describes the mean, not good, and not bad. Only few people have an exceptional talent. Most people will classify themselves in the third or fourth category. People that have an exceptional talent are able to explicate their talent. Please choose one possible category.

\section{Singing and music}

1. You are a professional singer or a professional musician playing one or more instruments.

2. You are able to read music and are a good singer or musician.

3. You sometimes sing a song for fun or play a simple melody on a piano or other musical instrument.

4. You neither sing nor play any musical instrument.

Arts

1. You have professional qualities regarding visual arts, dancing or acting.
2. You participate in visual arts, dancing or acting at amateur level.

3. You've average talents in arts

4. You are not talented in arts.

\section{Writing}

1. You are a professional writer, author, journalist or you could have been one.

2. You are able to write comprehensible and interesting letters or tales.

3. You are an average writer.

4. You have difficulties with writing a letter.

Language

1. You are able to speak and read three or more languages.

2. You are able to speak and read one foreign language fluently.

3. You are able to speak and read one foreign language good enough to get by.

4. You do not speak or read any foreign language.

\section{Chess (Chess, Checkers, Cards)}

1. You participate in highly competitive tournaments in one or more of these games.

2. You offer good resistance in this kind of games.

3. You are neither good nor bad in this kind of games.

4. You are not interested in this kind of games.

\section{Mathematics}

1. You have an exceptional mathematical understanding.

2. You perform better than most people on mathematical and numerical tasks.

3. You mathematical understanding is equivalent to most people.

4. You have difficulties with mathematical and numerical tasks.

Sports

1. You are athletically shaped and you are very good in one or more sports.

2. Your performance in sports is better than most people.

3. You do participate in one ore more sports for fun, without any exceptional performances.

4. You do not participate in any sport and you don't have any talent. 


\section{Memory}

1. You have an almost photographic memory for facts, numbers or details.

2. You have a good memory function.

3. Your memory function neither better nor worse than most people's memory.

4. You are memory function is not really good.

\section{Knowledge}

1. You have an exceptional knowledge about one or more subjects (for example: sports, Second World War, wines etc.) besides your everyday knowledge regarding your job.

2. You have good knowledge about one or more subjects and people often ask you questions.

3. Your knowledge is about the same as most people's knowledge.

4. You have less knowledge of facts than most people have.

\section{References}

Alarcon M, Knopik VS, DeFries JC (2000) Covariation of mathematics achievement and general cognitive ability in twins. J Sch Psychol 38:63-77. doi:10.1016/S0022-4405(99)00037-0

Benbow CP, Lubinski D (1993) Psychological profiles of the mathematically talented: some sex differences and evidence supporting their biological basis. Ciba Found Symp 178:44-59

Beunen G, Thomis M (1999) Genetic determinants of sports participation and daily physical activity. Int J Obes Relat Metab Disord 23(Suppl 3):S55-S63. doi:10.1038/sj.ijo.0800885

Boomsma DI, van den Bree MB, Orlebeke JF, Molenaar PC (1989) Resemblances of parents and twins in sports participation and heart rate. Behav Genet 19:123-141. doi:10.1007/BF01065888

Boomsma DI, de Geus EJ, Vink JM, Stubbe JH, Distel MA, Hottenga JJ, Posthuma D, van Beijsterveldt TC, Hudziak JJ, Bartels M, Willemsen G (2006) Netherlands Twin Register: from twins to twin families. Twin Res Hum Genet 9:849-857. doi:10.1375/ twin.9.6.849

Bouchard TJ Jr (1998) Genetic and environmental influences on adult intelligence and special mental abilities. Hum Biol 70:257-279

Bouchard C, Malina RM (1983) Genetics of physiological fitness and motor performance. Exerc Sport Sci Rev 11:306-339. doi: 10.1249/00003677-198301000-00011

Bouchard TJ Jr, Lykken DT, McGue M, Segal NL, Tellegen A (1990) Sources of human psychological differences: the Minnesota study of twins reared apart. Science 250:223-228. doi:10.1126/ science. 2218526

Brown MB, Engelman L, Frane JW, Hill MA, Jennrich RI, Toporek JD (1983) Frequency tables. In BMDP STATISTICAL SOFTWARE. University of California Press, Berkeley, p 155

Carey G (1992) Twin imitation for antisocial behavior: implications for genetic and family environment research. J Abnorm Psychol 101:18-25. doi:10.1037/0021-843X.101.1.18

Centraal Bureau voor de Statistiek (2009) Den Haag/Heerlen

Coon H, Carey G (1989) Genetic and environmental determinants of musical ability in twins. Behav Genet 19:183-193. doi:10.1007/ BF01065903
De Bruin AB, Rikers RM, Schmidt HG (2007) The influence of achievement motivation and chess-specific motivation on deliberate practice. J Sport Exerc Psychol 29:561-583

De Bruin AB, Smits N, Rikers RM, Schmidt HG (2008) Deliberate practice predicts performance over time in adolescent chess players and drop-outs: a linear mixed models analysis. Br J Psychol 99:473-497. doi:10.1348/000712608X295631

De Moor MH, Spector TD, Cherkas LF, Falchi M, Hottenga JJ, Boomsma DI, de Geus EJ (2007) Genome-wide linkage scan for athlete status in 700 British female DZ twin pairs. Twin Res Hum Genet 10:812-820. doi:10.1375/twin.10.6.812

De Zwart R, Warnaar MF, van Praag BMS, Diekstra RFW, van Praag CM (1993) Nationaal Scholierenonderzoek, 1992. Nationaal Instituut voor Budgetvoorlichting, Den Haag

Dickens WT, Flynn JR (2001) Heritability estimates versus large environmental effects: the IQ paradox resolved. Psychol Rev 108:346-369. doi:10.1037/0033-295X.108.2.346

Ericsson KA, Charness N (1994) Expert performance-its structure and acquisition. Am Psychol 49:725-747. doi:10.1037/0003066X.49.8.725

Ericsson KA, Krampe RT, Teschromer C (1993) The role of deliberate practice in the acquisition of expert performance. Psychol Rev 100:363-406. doi:10.1037/0033-295X.100.3.363

Eysenck HJ (1995) Genius. The natural history of creativity. Cambridge University Press, Cambridge

Falconer DS (1989) Introduction to quantitative genetics. Longman, London

Finkel D, Pedersen N, McGue M (1995) Genetic influences on memory performance in adulthood: comparison of Minnesota and Swedish twin data. Psychol Aging 10:437-446. doi:10.1037/ 0882-7974.10.3.437

Fuller JL, Thompson WR (1978) Foundations of behavior genetics. The C. V. Mosby Company, Saint Louis

Gagne F (1999) Nature of nurture? A re-examination of Sloboda and Howe's (1991) interview study on talent development in music. Psychol Music 27:38-51. doi:10.1177/0305735699271004

Howe MJ, Davidson JW, Sloboda JA (1998) Innate talents: reality or myth? Behav Brain Sci 21:399-407. doi:10.1017/S0140525X 9800123X

Jenkins JS (2005) Prodigies of nature. J R Soc Med 98:277-280. doi: 10.1258/jrsm.98.6.277

Joreskog K, Sorbom D, (2006) LISREL 8.80 student edition: scientific software international, Computer program

Koopmans JR, Boomsma DI, Heath AC, van Doornen LJ (1995) A multivariate genetic analysis of sensation seeking. Behav Genet 25:349-356. doi:10.1007/BF02197284

Lubinski D, Benbow CP, Webb RM, Bleske-Rechek A (2006) Tracking exceptional human capital over two decades. Psychol Sci 17:194-199. doi:10.1111/j.1467-9280.2006.01685.x

Lykken DT, McGue M, Tellegen A, Bouchard TJ Jr (1992) Emergenesis. Genetic traits that may not run in families. Am Psychol 47:1565-1577. doi:10.1037/0003-066X.47.12.1565

Macarthur DG, North KN (2005) Genes and human elite athletic performance. Hum Genet 116:331-339. doi:10.1007/s00439005-1261-8

Maia JA, Thomis M, Beunen G (2002) Genetic factors in physical activity levels: a twin study. Am J Prev Med 23:87-91. doi: 10.1016/S0749-3797(02)00478-6

McGue M, Hirsch B, Lykken DT (1993) Age and the self-perception of ability: a twin study analysis. Psychol Aging 8:72-80. doi: 10.1037/0882-7974.8.1.72

Neale MC (1994) Mx: statistical modeling, 2nd edn. Computer program

Neale MC, Eaves LJ, Kendler KS (1994) The power of the classical twin study to resolve variation in threshold traits. Behav Genet $24: 239-258$ 
Plomin R, DeFries JC, Loehlin JC (1977) Genotype-environment interaction and correlation in the analysis of human behavior. Psychol Bull 84:309-322

Plomp HN, Kuipers H, van Oers ML (1991) Smoking, alcohol consumption and the use of drugs by schoolchildren from the age of 10. Results of the fourth Dutch National Youth Health Care Survey 1988/1989. Vu University Press, Amsterdam

Posthuma D, Boomsma DI (2005) Mx scripts library: structural equation modeling scripts for twin and family data. Behav Genet 35:499-505

Rijsdijk FV, Boomsma DI (1997) Genetic mediation of the correlation between peripheral nerve conduction velocity and IQ. Behav Genet 27:87-98

Rijsdijk FV, Vernon PA, Boomsma DI (2002) Application of hierarchical genetic models to Raven and WAIS subtests: a Dutch twin study. Behav Genet 32:199-210

Ruthsatz J, Detterman D, Griscom W, Collins JM (2008) Becoming an expert in the musical domain: it takes more that just practice. Intelligence 36:330-338

Sangster B, Abrahamse APJ (1995) Sportbeoefening: kerngegevens 1991 (a sports participation: key figures 1991). In: Vademecum Gezondheidsstatistiek Nederland (Vademecum of Health Statistics of the Netherlands). Voorburg: Centraal Bureau voor de Statistiek

Sternberg RJ (1993) Procedures for identifying intellectual potential in the gifted: a perspective on alternative "metaphors of mind". In: Heller KA, Monks FJ, Passow AH (eds) International handbook of research and development of giftedness and talent. Pergamon Press Ltd, Oxford, pp 185-207

Stromswold K (2001) The heritability of language: a review and meta-analysis of twin, adoption, and linkage studies. Language 77:647-723

Stubbe JH, Boomsma DI, de Geus EJ (2005) Sports participation during adolescence: a shift from environmental to genetic factors. Med Sci Sports Exerc 37:563-570

Stubbe JH, Boomsma DI, Vink JM, Cornes BK, Martin NG, Skytthe A, Kyvik KO, Rose RJ, Kujala UM, Kaprio J, Harris JR, Pedersen NL, Hunkin J, Spector TD, de Geus EJ (2006) Genetic influences on exercise participation in 37,051 twin pairs from seven countries. PLoS ONE 1:e22

Thompson LA, Detterman DK, Plomin R (1991) Associations between cognitive-abilities and scholastic achievement-genetic overlap but environmental differences. Psychol Sci 2:158-165

WAIS-III (1997) Lisse, Swets and Zeitlinger. Dutch version. Manual

Walker SO, Petrill SA, Spinath FM, Plomin R (2004) Nature, nurture and academic achievement: a twin study of teacher assessments of 7-year-olds. Br J Educ Psychol 74:323-342

Wijsman EM, Robinson NM, Ainsworth KH, Rosenthal EA, Holzman T, Raskind WH (2004) Familial aggregation patterns in mathematical ability. Behav Genet 34:51-62

Willemsen G, Posthuma D, Boomsma DI (2005) Environmental factors determine where the Dutch live: results from the Netherlands twin register. Twin Res Hum Genet 8:312-317 